\title{
Green Photoluminescent Methodology for Aluminium Traces Quantification in 24-Hour Urine of Subjects with Different Exposition to Tobacco Smoke
}

\author{
Débora G. Santarossa1, María C. Talioº ${ }^{1}$ Liliana P. Fernández ${ }^{12^{*}}$ \\ ${ }^{1}$ Instituto de Química de San Luis (INQUISAL-CONICET), Chacabuco y Pedernera, San Luis, Argentina \\ ${ }^{2}$ Área de Química Analítica, Facultad de Química, Bioquímica y Farmacia, Universidad Nacional de San Luis, San Luis, Argentina \\ Email: *lfernand@unsl.edu.ar
}

How to cite this paper: Santarossa, D.G., Talio, M.C. and Fernández, L.P. (2018) Green Photoluminescent Methodology for Aluminium Traces Quantification in 24-Hour Urine of Subjects with Different Exposition to Tobacco Smoke. American Journal of Analytical Chemistry, 9, 514-528.

https://doi.org/10.4236/ajac.2018.910038

Received: September 3, 2018

Accepted: October 22, 2018

Published: October 25, 2018

Copyright $\odot 2018$ by authors and Scientific Research Publishing Inc. This work is licensed under the Creative Commons Attribution International License (CC BY 4.0).

http://creativecommons.org/licenses/by/4.0/

CC) (i) Open Access

\begin{abstract}
The aim of this work has been to evaluate the aluminium ( $\mathrm{Al}(\mathrm{III})$ ) traces contents in 24-hour urine samples from subjects with different tobacco smoke expositions using a new methodology with 1,4-dihydroxy-9, 10-anthraquinone (Quinizarine, QZ) as a fluorosphore. Biological samples were tested using commercial reagent strips and clinical parameters. $\mathrm{Al}$ (III) was determined complexing with QZ followed by a solid phase extraction step using Nylon membranes as a solid support. The analyte was subsequently quantified by solid surface fluorescence (SSF, $\lambda_{\mathrm{em}}=573, \lambda_{\mathrm{exc}}=490$ ) with a detection limit of $0.88 \mu \mathrm{g} \mathrm{L}^{-1}$ and quantification limit of $2.69 \mu \mathrm{g} \mathrm{\textrm {L } ^ { - 1 }}$. The calibration curve was linear from 2.69 to $499.13 \mu \mathrm{g} \mathrm{L^{-1 }} \mathrm{Al}(\mathrm{III})\left(\mathrm{R}^{2}=0.9973\right)$. Urine samples were successfully analysed with an average recovery close to $100 \%$. Solid phase extraction step showed efficacy to eliminate foreign ions and the highly fluorescent matrix own of urine. Results were validated by electrothermal atomic absorption spectrometry (ETAAS) with an adequate concordance. The new methodology has low operation cost with simple instrumentation and without organic solvent.
\end{abstract}

\section{Keywords}

Tobacco, Aluminium Traces, 1,4-dihydroxy-9,10-anthraquinone (Quinizarine), Solid Phase Extraction, Solid Surface Fluorescence, Urine samples

\section{Introduction}

Aluminium is a human non-essential metal that makes up about $8 \%$ of the 
Earth's crust. The sources of exposure of population in general are very varied: the consumption water treated with aluminum sales during the purification process, foods preservatives and colorants containing this metal, pharmaceuticals as antacids, in the production, manufacture and welding of aluminium [1] [2] [3] [4]. In addition, different compounds of this metal such as aluminium hydroxide, aluminium oxide, aluminium silicate, aluminium sulfate are used the process of manufacture of cigarettes in order to accelerate the process of combustion and whitening of the ashes which achieves a more aesthetic and consumable product [5] [6].

If the levels of aluminium exposure surpass the capacity of natural detoxification by the part of the organism, it will be accumulated, mainly in the bones, the liver and the brain, being considering as possible cause of renal osteodystrophy, Alzheimer's disease and Parkinson's disease [7] [8] [9]. Monitoring aluminium levels is of paramount importance in the field of clinical chemistry to prevent diseases associated with this metal. Between other biological fluids, urine is particularly attractive because the same patient can obtain the sample by non-invasive sampling procedure.

Tobacco consuming is one of the worst threatens to public health world has faced, due to it is one of the main risk factors of chronic diseases like cancer and pulmonary and cardiovascular diseases [10]. In Argentina, every year more than 40,000 of smokers die because of diseases related to tobacco. Although facts reveal that tobacco use has decreased in the latest 8 years, its effects continue to be alarming which conduct specialists to carry on working to dismiss cigarette consumption [11].

Many studies have been done related to the harmful effects of carbon monoxide, nicotine, tar, irritants and other damaging gases in the tobacco smoke [12]. However, possible effects of cigarettes heavy metals on human biochemical processes have been less studied [13] [14] [15].

The analytical methods used in aluminium determination at trace levels in complex matrices must be sensitive, selective, precise and faster [16]. Spectrofluorometry [17] [18], flame atomic absorption spectrometry (FAAS) [19] and atomic absorption spectrometry in graphite furnace (ETAAS) [20] [21] have been successfully applied.

However, due to the low level of metal concentration in biological fluids, the introduction of a preconcentration step prior to instrumental detection results indispensable. The traditional methods of preconcentration and separation for metal ions are liquid-liquid extraction, coprecipitation and ion exchange, between others. These methods often require large amounts of high purity organic solvents, which are harmful to health and cause environmental problems [22] [23] [24] [25] [26].

Solid phase extraction (SPE) is being widely used for the analytes preconcentration or separation showing advantages such as high enrichment factors, minimum costs due to low reagent consumption, flexibility and easy automati- 
zation [27]. Different solid materials such as filter papers, silica gel, exchange resins, aluminium oxides, $\mathrm{C}_{18}$ membranes, and cyclodextrins, among others have been successfully employed as supports for SPE. Recently, Nylon membranes have proved to be a suitable support for the luminescent detection of organic compounds showing efficacy in the elimination of highly fluorescent matrix [28] [29] [30]. The experimental results showed that this support has good selectivity, low background signal and can be used without previous treatment.

In a previous work, our research group determined $\mathrm{Al}$ (III) traces contents present in drink and tap waters of San Luis city, with the aim to know exposition levels to this metal [31], using a CPE-fluorescence combined method. In this opportunity, attending to aluminium is one of the 4700 chemical compounds contained in cigarette smoke, a new methodology is proposed for the study of the tobacco incidence in $\mathrm{Al}$ (III) levels in urine samples of population of the same geographic zone. The separation/chemisorption of $\mathrm{Al}(\mathrm{III})$ complexed with QZ on Nylon membranes is proposed for the subsequent quantification by solid surface fluorescence (SSF) in 24-hour urine samples of subjects with different levels of tobacco exposure. The experimental variables that affect the sensitivity and precision of the proposed method were investigated and optimized in detail.

\section{Material and Methods}

\subsection{Instruments}

Shimadzu RF-5301 PC spectrofluorometer (Shimadzu Corporation Analytical Instrument Division, Kyoto, Japan) equipped with a 150W Xenon lamp and solid sample holder with a GF-UV35 filter were used.

Measurements of aluminium were performed with a Shimadzu Model AA-6800 Atomic Absorption Spectrometer (Tokyo, Japan) equipped with a deuterium background corrector, EX7-GFA electrothermal atomizer and ASC-6100 autosampler. L'vov graphite tubes (Shimadzu, Tokyo, Japan) was used in all experiments. Aluminium hollow-cathode lamps (Hamamatsu, Photonics K., Japan) wereemployed as radiation sources. Wave length used was $309.4 \mathrm{~nm}$ (SlitWidth: 0.5 $\mathrm{nm}$ ) using a pyrolysis times of $10 \mathrm{~s}$ at $250^{\circ} \mathrm{C}$ and atomization time of $3 \mathrm{~s}$ at $2500^{\circ} \mathrm{C}$.

Adjustments of $\mathrm{pH}$ were carried out using Orion Expandable Ion Analyzer pH-meter (Orion Research, MA, USA) Model EA 940 with a combined glass electrode.

A centrifuge equipment (ROLCO SRL, Buenos Aires, Argentine) with an angle rotor (6-place, $3500 \times \mathrm{g}$ ) was used for urine samples processing.

Nylon membranes (Millipore, Tullagreen, Carrigtwohill Co. Cork, Ireland) $0.45 \mu \mathrm{m}$ pore size and $47 \mathrm{~mm}$ diameter were used in chemisorption studies.

\subsection{Reagents}

Standard solution of $1000 \mathrm{mg} \mathrm{L}^{-1} \mathrm{Al}$ (III) was prepared dissolving appropriate amounts of $\mathrm{Al}\left(\mathrm{NO}_{3}\right)_{3} \cdot 9 \mathrm{H}_{2} \mathrm{O}$ (E-Merck, Darmstadt, Germany) in ultrapure water. The standard stock solution was stored in a glass bottle at $4^{\circ} \mathrm{C}$ in the dark. Lower 
concentration standards were obtained weekly by dilution of the stock solutions.

Solution of 1,4-dihydroxy-9,10-anthaquinona (Quinizarine, QZ) $1 \times 10^{-3} \mathrm{~mol}$

$\mathrm{L}^{-1}$ (E-Merck, Darmstadt, Germany), fluorescein (E-Merck, Darmstadt, Germany), chrome azurol S (CAS, E-Merck, Darmstadt, Germany) were prepared by dissolving appropriate amounts of each reagent in ethanol (Sigma Chemical Co., St. Louis, MO, United States) and were kept the in refrigerator $\left(4^{\circ} \mathrm{C}\right)$ for one week.

Buffer $1.0 \mathrm{~mol} \mathrm{~L}^{-1}$ solution was prepared using acetic acid (Riedel-de Haen) and the desired $\mathrm{pH} 5$ was obtained by adding $\mathrm{NaOH}$ (Mallinckrodt Chemical Works) solution.

Surfactant solution of sodium dodecyl sulfate (SDS, Tokyo Kasei Industries) 2 $\times 10^{-2} \mathrm{~mol} \mathrm{~L}^{-1}$ was prepared using an adequate weight of reagent and dissolving them in ultrapure water.

Urinalysis reagent strips (Insight, ACON Laboratories, Inc. Germany) were used.

All chemicals used were analytical grade and ultrapure water was used throughout.

\subsection{Sample Collection and Treatments}

\subsubsection{Biological Samples}

Per regulation, all participants of the present research signed a written informed consent.

Urine samples of $24 \mathrm{~h}$ of healthy subjects with different levels of tobacco addiction were collected in polystyrene bottles without the addition of chemical stabilizers. The volume of each sample was measured (diuresis) in order to calculate the real concentration of $\mathrm{Al}(\mathrm{III})$. Then, approximately $10 \mathrm{~mL}$ of each sample were centrifuged at $3500 \times \mathrm{g}$ during 20 minutes. After that, supernatants were separated, frozen at $-18^{\circ} \mathrm{C}$, and reserved for analysis.

Biological samples were physically characterized, namely colour, odor and appearance, presence of sediment, blood and mucus, in order to establish variables that could affect the obtained results. Additionally, urine samples were tested using commercial reagent strips and clinical parameters $(\mathrm{pH}$, urobilinogen, glucose, ketones, bilirubin and proteins, among others) were determined. Processed samples can be mainly considered within the normal physical and clinical parameters.

In order to assure the obtaining on of representative samples, subjects received detailed information about the collection protocol:

- Do not intake vitamin or mineral aggregated $36 \mathrm{~h}$ before urine collection.

- Do not drink tap water during $24 \mathrm{~h}$ previous to sample collection.

- Samples must be directly remitted to laboratory for analysis; if it is not possible, they must be preserved at $4^{\circ} \mathrm{C}$ until analysis.

\subsubsection{Treatment of Samples to Remove Calcium}

A volume of $2 \mathrm{~mL}$ of urine sample, $2 \mathrm{~mL}$ of water ultrapure and $1 \mathrm{~mL}$ of $4 \%$ 
ammonium oxalate were placed in a centrifuge tube. It was vigorously stirred and left to rest for 30 minutes to precipitate the calcium oxalate, then centrifuged 15 minutes at $3500 \times \mathrm{g}$. The supernatant was saved to perform the general procedure.

\subsection{General Procedure-Solid Phase Extraction}

A $1750 \mu \mathrm{L}$ QZ solution $\left(1 \times 10^{-5} \mathrm{~mol} \mathrm{~L}^{-1}\right)$, $\mathrm{Al}$ (III) sample/standard (2.69 to $\left.499.13 \mu \mathrm{g} \mathrm{L}^{-1}\right), 500 \mu \mathrm{L}$ acetic acid buffer $\left(1 \mathrm{~mol} \mathrm{~L}^{-1}, \mathrm{pH} 5\right)$, and $100 \mu \mathrm{L}$ SDS $(2 \times$ $10^{-2} \mathrm{~mol} \mathrm{~L}^{-1}$ ) were placed in a volumetric flask. The mixture was diluted to 10 $\mathrm{mL}$ with ultrapure water and was filtrated across Nylon membranes, using a vacuum pump and dried at room temperature. $\mathrm{Al}(\mathrm{III})$ was determined on the membranes by SSF at $\lambda_{\mathrm{em}}=572 \mathrm{~nm}$ and $\lambda_{\mathrm{exc}}=490 \mathrm{~nm}$, using a solid sample holder (Figure 1).

\subsection{Interferences Study}

Different amounts of foreign ions, which may be present in samples, $(1 / 1,1 / 10$, $1 / 50$ and 1/100 $\mathrm{Al}$ (III)/interferent ratio) were added to the test solution containing $24.95 \mu \mathrm{g} \mathrm{L}^{-1} \mathrm{Al}(\mathrm{III})$ and the General Procedure was applied.

\subsection{Dilution Test}

In order to establish the proper volume of each urine sample for realizing $\mathrm{Al}$ (III) determination, several sample volumes were assayed. The adequate dilution for each sample was that signal which intensities fall into the linearity range of the developed methodology. Dilution test was of $100 \mu \mathrm{L}$ for subjects with minor exposition and of $0.025 \mu \mathrm{L}$ for the most exposed subjects. These dilution factors were adopted for the following studies. $\mathrm{Al}$ (III) contents were determined by the proposed methodology, employing the obtained volume samples through test dilution.

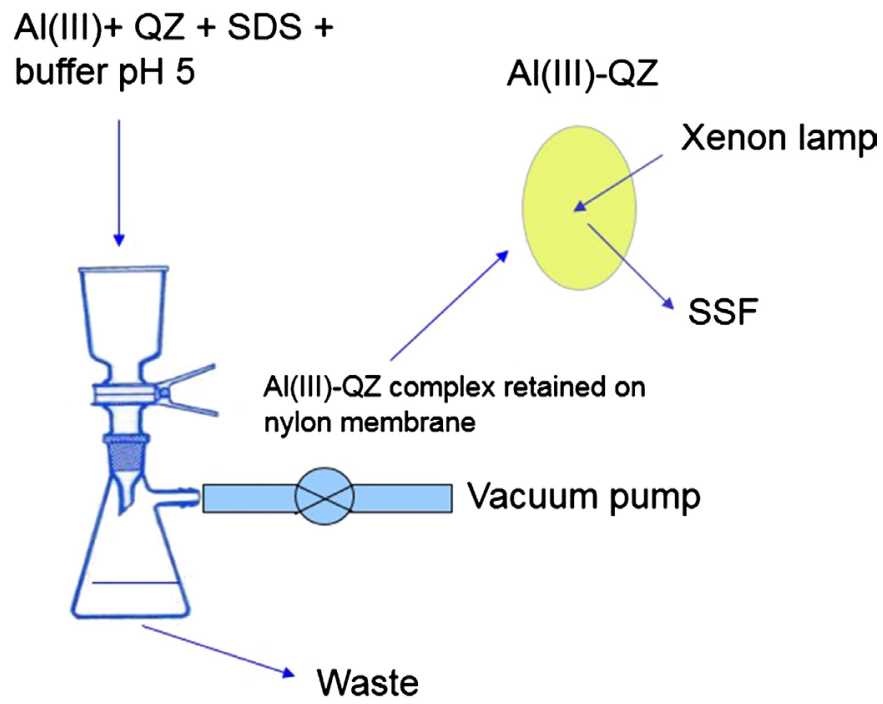

Figure 1. Schematic representation of general procedure of developed methodology. 


\subsection{Accuracy Study}

Volumes of $0.1 \mathrm{~mL}$ of urine samples were spiked with increasing amounts of $\mathrm{Al}$ (III) (24.95 and $49.91 \mu \mathrm{g} \mathrm{L} \mathrm{L}^{-1}$ ). Aluminium contents were determined by proposed methodology.

\subsection{Precision Study}

The repeatability (within-day precision) of the method was tested for urine replicate samples $(\mathrm{n}=3)$ spiked with 24.95 and $49.91 \mu \mathrm{g} \mathrm{L} \mathrm{L}^{-1}$ of $\mathrm{Al}(\mathrm{III})$ and metal contents were determined by proposed methodology.

\subsection{Validation}

$\mathrm{Al}(\mathrm{III})$ contents in water samples were determined by ETAAS, using operational conditions previously consigned in apparatus item.

\section{Results and Discussion}

Quinizarine (4-dihydroxy-9,10-anthraquinone, QZ) is an organic dye derived from anthraquinone characterized because it forms neutral chelates with metal ions. The formation of a highly fluorescent pink-red complex between $\mathrm{Al}(\mathrm{III})$ and QZ will depend on the nature of the solvent, the molar ratio and the medium $\mathrm{pH}$ [32] [33] [34].

In order to study the possibility of evaluating the $\mathrm{Al}(\mathrm{III})$ traces content as $\mathrm{QZ}$ complex in 24 hours urine, a separation step results necessary because of the urine highly fluorescent matrix. A solid phase extraction (SPE) step was investigated prior the instrumental determination of Al(III) by SSF. The SPE offers a double beneficial effect: on the one hand, the preconcentration of the analyte, due to its retention in a small area of the solid support and on the other, the improvement of the selectivity, due to the elimination of fluorescent components present in the matrix and other possible interferents.

The experimental parameters that influence the SPE procedure and the SSF determination were studied and optimized.

Systems were prepared containing QZ solution and increasing concentrations of $\mathrm{Al}(\mathrm{III})$ at $\mathrm{pH} 5$ using acetic acid/acetate buffer; they were filtered through solid support, dried at to room temperature and SSF signal of each system was determined using a solid sampler holder. It was evidenced that the presence of $\mathrm{Al}(\mathrm{III})$ exalted the SSF of the fluorophore (Figure 2).

Retention of the QZ-Al (III) complex was studied using different solid supports. Some of studied solid supports were not effective for the QZ-Al (III) retention; in Table 1, the obtained results are shown. The retention levels for each analyzed supports were verified by measuring SSF intensity at $\lambda_{\mathrm{em}}=573 \mathrm{~nm}$, using a $\lambda_{\text {exc }}=490$. The best result was obtained when Nylon membranes were used.

The next optimized parameter was the $\mathrm{pH}$ of systems filtered through the $\mathrm{Ny}$ lon membranes. The $\mathrm{pH}$ value of the aqueous systems containing a constant concentration of $\mathrm{Al}$ (III) was adjusted between 2.8 and 10, by adding a solution 


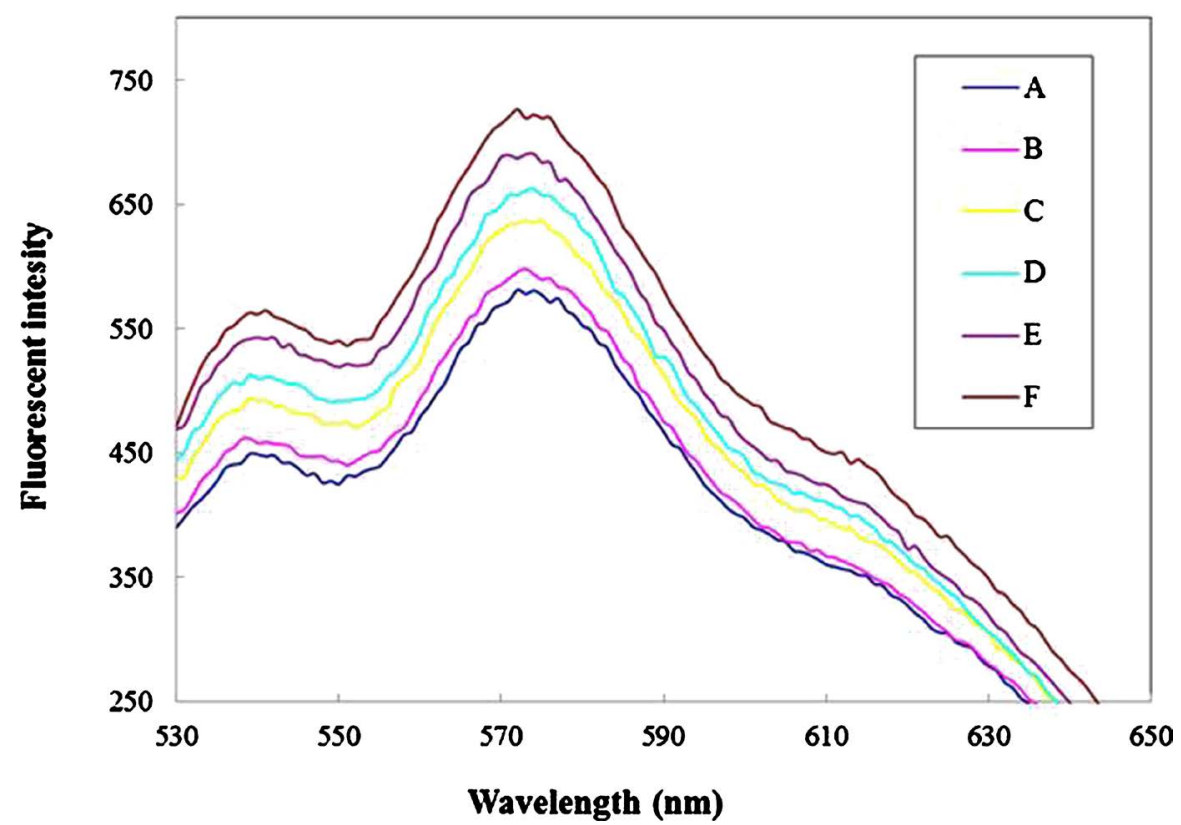

A: Blank solution QZ $\left(\mathrm{C}_{\mathrm{QZ}}=1.75 \times 10^{-6} \mathrm{~mol} \mathrm{~L}^{-1}\right)$. B: Idem A with Al(III) $9.98 \mu \mathrm{g} \mathrm{L}^{-1}$. C: Idem A with $\mathrm{Al}(\mathrm{III}) 24.95 \mu \mathrm{g} \mathrm{L}^{-1}$. D: Idem A with Al(III) $49.91 \mu \mathrm{g} \mathrm{L} \mathrm{L}^{-1}$. E: Idem A with $\mathrm{Al}(\mathrm{III}) 74.86 \mu \mathrm{g} \mathrm{L}{ }^{-1}$. F: Idem A with Al(III) $99.82 \mu \mathrm{g} \mathrm{L}^{-1}$. Conditions: $\lambda_{\mathrm{em}}=570 \mathrm{~nm} ; \lambda_{\mathrm{exc}}=490 \mathrm{~nm} ; \mathrm{pH} 5 ; \mathrm{C}_{\text {buffer acetic/acetate }}=5 \times 10^{-2}$ $\mathrm{mol} \mathrm{L}^{-1} ; \mathrm{C}_{\mathrm{SDS}}=5 \times 10^{-4} \mathrm{~mol} \mathrm{~L}^{-1}$. Other experimental conditions are described under procedure.

Figure 2. Solid surface fluorescence spectra for QZ/Al(III) system.

Table 1. Study of retention of QZ-Al(III) on different types of membranes as solid supports.

\begin{tabular}{cc}
\hline Type of membrane & Observations \\
\hline $\begin{array}{c}\text { Cellulose acetate (Whatman) } \\
\text { Pore size: } 0.45 \mu \mathrm{m}\end{array}$ & retention: (-) \\
Immobilon (+) (Millipore) & \\
Pore size: $0.45 \mu \mathrm{m}$ & retention: $(-)$ \\
Teflon & \\
(Millipore) Pore size: $1 \mu \mathrm{m}$ & retention: $(-)$ \\
Mixed Esters & \\
Filterpaper & retention: $(-)$ \\
(Schleicher \& Schuell) Pore size: $0.45 \mu \mathrm{m}$ & \\
Filter paper & retention: $(-)$ \\
(S \& S) Blue ribbon & \\
Nylon & retention: $(-)$ \\
(Millipore) Pore size: $0.45 \mu \mathrm{m}$ & \\
\hline
\end{tabular}

$\mathrm{Al}$ (III) concentration $=24.95 \mu \mathrm{g} \mathrm{L}^{-1}$; $\mathrm{QZ}$ concentration $=1.75 \times 10^{-6} \mathrm{~mol} \mathrm{~L}^{-1} ;(-)=\mathrm{QZ}-\mathrm{Al}(\mathrm{III})$ not retained on solid support. $(+)=\mathrm{QZ}-\mathrm{Al}(\mathrm{III})$ retained on solid support.

of acetic acid/ acetate buffer. Figure 3 shows the results of this study. It could be observed that the highest emission for $\mathrm{Al}$ (III)-QZ was obtained at $\mathrm{pH}$ 5. Subsequently, the buffer concentration was tested from $1 \times 10^{-2}$ to $0.1 \mathrm{~mol} \mathrm{~L}^{-1}$ to obtain the maximum fluorescent signal. A buffer concentration of $5 \times 10^{-2} \mathrm{~mol} \mathrm{~L}^{-1}$ was chosen as optimal. 
The concentration of the chelating reagent was also studied, in order to assure the quantitative association of $\mathrm{Al}(\mathrm{III})$ with QZ; studies were carried out maintaining a constant concentration of the metal and varying the concentration of QZ between $2 \times 10^{-7}$ to $2 \times 10^{-6} \mathrm{~mol} \mathrm{~L}^{-1}$. The concentration of $1.75 \times 10^{-6} \mathrm{~mol}$ $\mathrm{L}^{-1}$ was selected as optimal, which is high enough to guarantee an excess of QZ with respect to the expected $\mathrm{Al}(\mathrm{III})$ contents in studied samples (Figure 4).

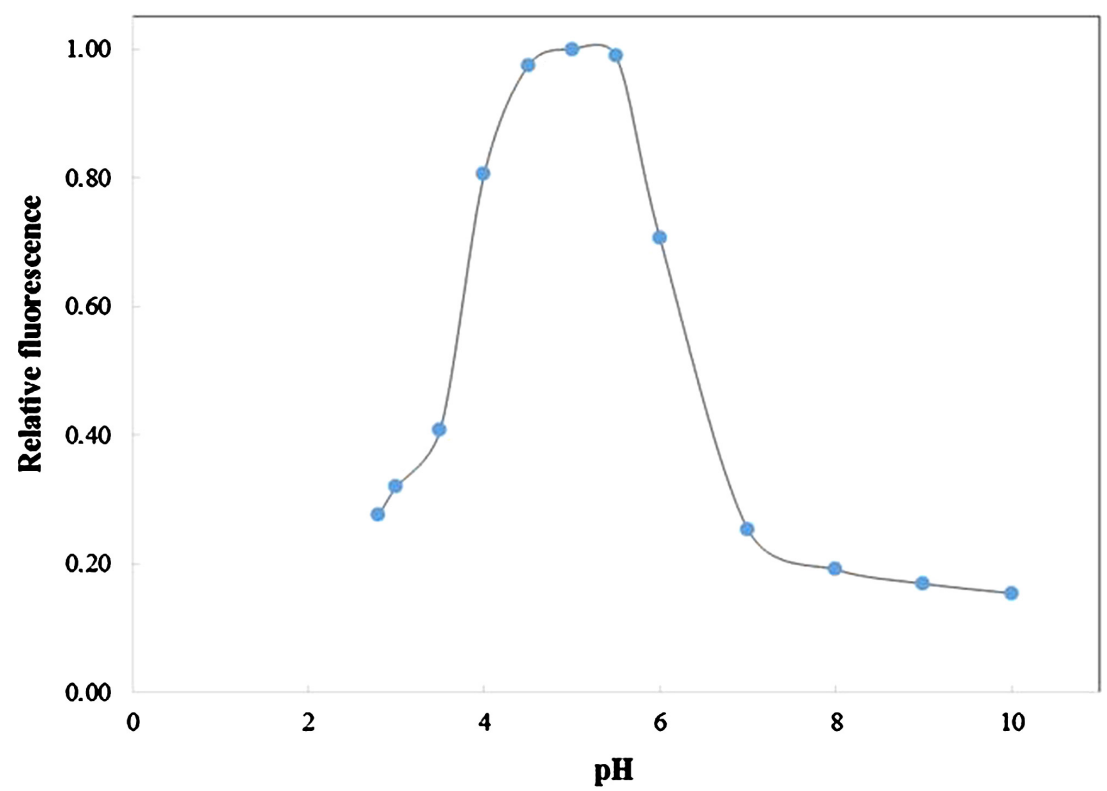

Conditions: $\lambda_{\mathrm{em}}=570 \mathrm{~nm} ; \lambda_{\mathrm{exc}}=470 \mathrm{~nm} ; \mathrm{C}_{\mathrm{QZ}}=1.75 \times 10^{-6} \mathrm{~mol} \mathrm{~L}^{-1} ; \mathrm{C}_{\mathrm{SDS}}=5 \times 10^{-4} \mathrm{~mol} \mathrm{~L}^{-1} ; \mathrm{C}_{\mathrm{Al}(\mathrm{III})}=$ $24.95 \mu \mathrm{g} \mathrm{L} \mathrm{L}^{-1}$. Other experimental conditions are described under procedure.

Figure 3. Influence of $\mathrm{pH}$ on QZ/Al(III) SSF signal.

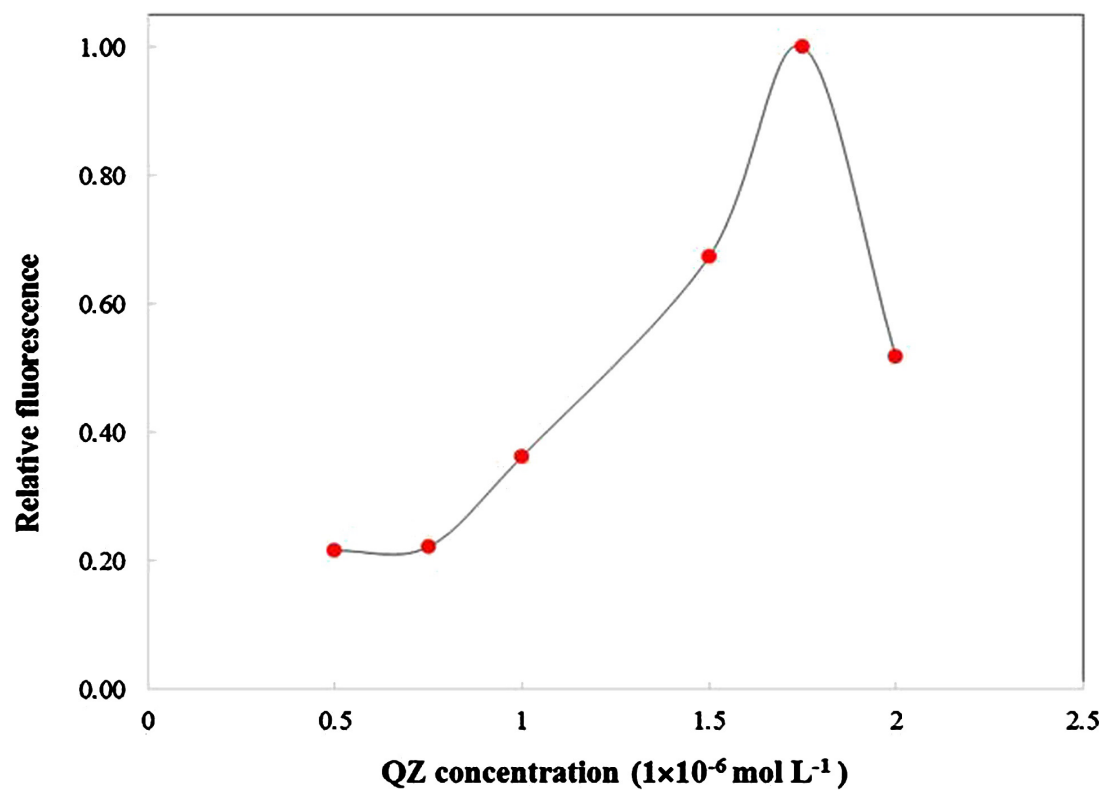

Conditions: $\lambda_{\mathrm{em}}=570 \mathrm{~nm} ; \lambda_{\mathrm{exc}}=490 \mathrm{~nm} ; \mathrm{C}_{\text {buffer acetic/acetate }}=5 \times 10^{-2} \mathrm{~mol} \mathrm{~L}^{-1} ; \mathrm{pH}=5 ; \mathrm{C}_{\mathrm{SDS}=} 5 \times 10^{-4}$ $\mathrm{mol} \mathrm{L}^{-1} ; \mathrm{C}_{\mathrm{Al}(\mathrm{III})}=24.95 \mu \mathrm{g} \mathrm{L} \mathrm{L}^{-1}$. Other experimental conditions are described under procedure.

Figure 4. Effect of QZ concentration on the QZ/Al(III) SSF signal. 
The use of surfactants in molecular fluorescence provides some advantages that improve the determination of the analyte under study. In this way, micellar media are used to minimize intermolecular interactions between the analyte and the constituents of the sample matrix. In addition, the photophysical properties of the fluorescent solutes can be altered in the micellar medium thus improving the fluorescent sensitivity [35]. The effect of different surfactants in the SPE for the quantification of the $\mathrm{Al}(\mathrm{III})-\mathrm{QZ}$ by SSF was studied. It was evidenced that the anionic surfactant SDS in a concentration of $5 \times 10^{-4} \mathrm{~mol} \mathrm{~L}^{-1}$ increased the fluorescent intensity of $\mathrm{Al}(\mathrm{III})$ complex (Figure 5).

\section{Analytical Parameters}

Table 2 summarizes the studied experimental variables, the optimal values for

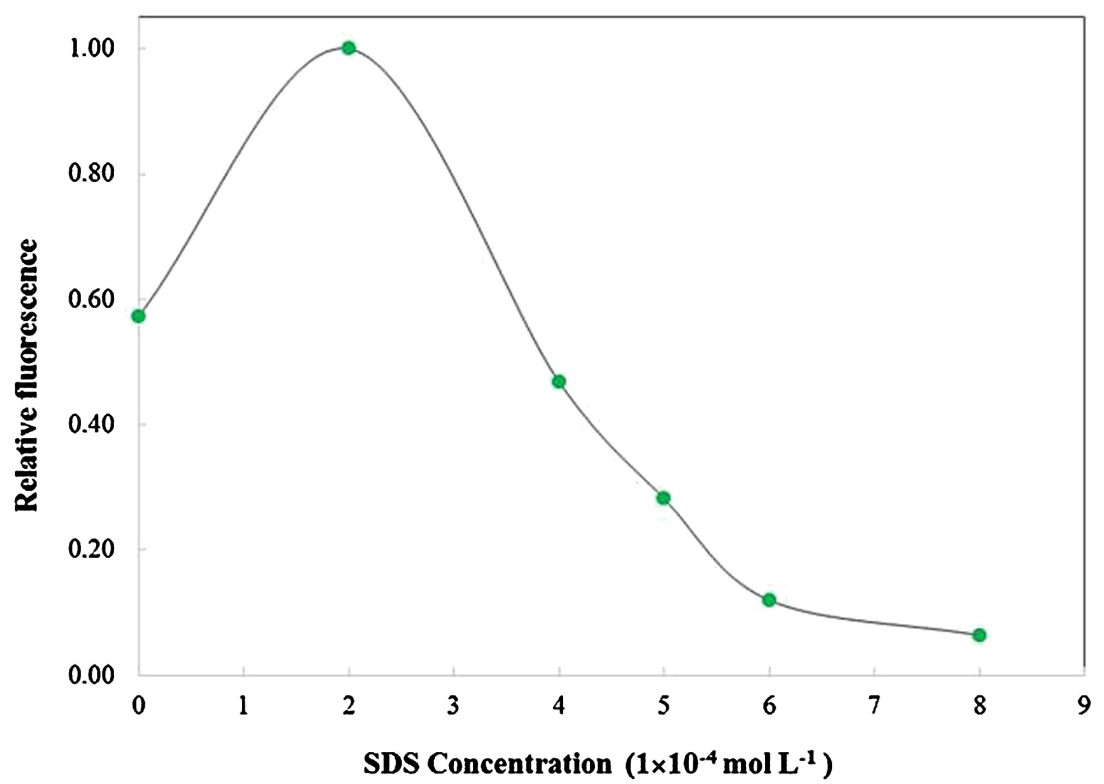

Conditions: $\lambda_{\mathrm{em}}=570 \mathrm{~nm} ; \lambda_{\mathrm{exc}}=490 \mathrm{~nm} ; \mathrm{C}_{\mathrm{QZ}}=1.75 \times 10^{-6} \mathrm{~mol} \mathrm{~L}^{-1} ; \mathrm{C}_{\text {buffer acetic/acetate }}=5 \times 10^{-2} \mathrm{~mol} \mathrm{~L}^{-1}$; $\mathrm{pH}=5 ; \mathrm{C}_{\mathrm{Al}(\mathrm{III})}=24.95 \mu \mathrm{g} \mathrm{L}^{-1}$. Other experimental conditions are described under procedure.

Figure 5. Influence of anionic surfactant concentrations SDS on QZ/Al(III) SSF signal.

Table 2. Optimal experimental conditions and analytical parameters for QZ-Al(III) determination.

\begin{tabular}{ccc}
\hline Parameters & Studied range & Optimal conditions \\
\hline Type of membrane & Nylon, cellulose acetate, esters, teflon, filter paper & Nylon \\
$\mathrm{pH}$ & $2.8-10$ & 5 \\
Concentration buffer & $1 \times 10^{-2}-0.1 \mathrm{~mol} \mathrm{~L}^{-1}$ & $5 \times 10^{-2} \mathrm{~mol} \mathrm{~L}^{-1}$ \\
Concentration QZ & $2 \times 10^{-7}-2 \times 10^{-6} \mathrm{~mol} \mathrm{~L}^{-1}$ & $1.75 \times 10^{-6} \mathrm{~mol} \mathrm{~L}^{-1}$ \\
Concentration SDS & $0-1 \times 10^{-3} \mathrm{~mol} \mathrm{~L}^{-1}$ & $5 \times 10^{-4} \mathrm{~mol} \mathrm{~L}^{-1}$ \\
LOD & - & $0.8877 \mu \mathrm{g} \mathrm{L}^{-1}$ \\
LOQ & - & $2.69 \mu \mathrm{g} \mathrm{L}^{-1}$ \\
LOL & - & $2.69-499.13 \mu \mathrm{g} \mathrm{L}^{-1}$ \\
$\mathrm{R}^{2}$ & - & 0.9971
\end{tabular}


separation/determination of $\mathrm{Al}(\mathrm{III})-\mathrm{QZ}$ on Nylon membranes and obtained analytical parameters for the developed methodology. The limit of detection (LOD) was calculated as $3.3 \mathrm{~s} / \mathrm{m}$ [36], where $\mathrm{s}$ is the standard deviation of 10 successive means of the blank and $\mathrm{m}$ is the slope of the calibration curve (calibration sensitivity). The limit of quantification (LOQ) was calculated as $10 \mathrm{~s} / \mathrm{m}$. The range of linearity was evaluated by checking the linear regression coefficient $\left(\mathrm{R}^{2}\right)$ of the calibration curve. The linearity of the calibration curve was considered acceptable when $\mathrm{R}^{2}>0.9971$.

\section{Interferences Study}

The effect of foreign ions on the recovery of $\mathrm{Al}(\mathrm{III})$ was tested. An ion was considered as interferent when it caused a variation in the SSF signal of the analyte greater than $\pm 5 \%$. The assayed ions for interferences study were selected considering the nature of the sample analysed and the possible presence because of exposure to tobacco smoke. Figure 6 shows the obtained results for assayed ions. At optimal working conditions an adequate tolerance was obtained for interferent/ $\mathrm{Al}(\mathrm{III}) 100 / 1$ ratio, at exception made of $\mathrm{Ca}$ (II), that it must be removed as it has been detailed in 2.3.2 Treatment of samples to remove calcium.

\section{Applications}

To evaluate the usefulness of the developed methodology in the determination of $\mathrm{Al}(\mathrm{III})$ traces, samples of 24-hour urine from subjects with different exposition to tobacco were studied.

Attending to smoking habits, the studied subjects can be described as follow:

Sample 1-3: Non-smokers subjects.

Sample 4 and 5: Smoker subjects of 10 cigarettes/day.

Sample 6: Smoker subject of 20 cigarettes/day.

Sample 7: Water pipe smoker.

Once in the laboratory, urine samples were observed and characterized respect to physical appearance in order to establish variables that could interfere with $\mathrm{Al}(\mathrm{III})$ determinations. All processed samples can be namely considered within the normal physical parameters.

Samples were centrifuged for $10 \mathrm{~min}$ at $1000 \times \mathrm{g}$. Supernatants were reserved for $\mathrm{Al}(\mathrm{III})$ examination. Urine samples were tested using commercial reagent strips and clinical parameters $\mathrm{pH}$, urobilinogen, glucose, ketones, bilirubin, proteins, nitrite, blood, specific gravity and leucocytes were determined. Processed samples can be mainly considered within the normal clinical parameters.

The accuracy of the methodology was performed using the standard addition method. Diluted urine samples $(100 \mu \mathrm{L}, \mathrm{n}=3)$ were spiked with increasing amounts of $\mathrm{Al}(\mathrm{III})$. The repeatability (within-day precision) of the method was evaluated carrying out the proposed methodology, 3 times for each sample.

Obtained results showed satisfactory agreement with adequate precision and recovery. Table 3 shows the recovery results achieved for each urine sample. 
As there were not available Certified Materials, in order to check the accuracy of the proposed method, a comparative analysis by electrothermal atomic absorption spectrometry (ETAAS) was carried out using the conditions published in previous works [31].

A remarkable peace of data is the ample range of variability of $\mathrm{Al}$ (III) contents in the control groups (Samples 1 to 3 ). This leads us to believe that exist others

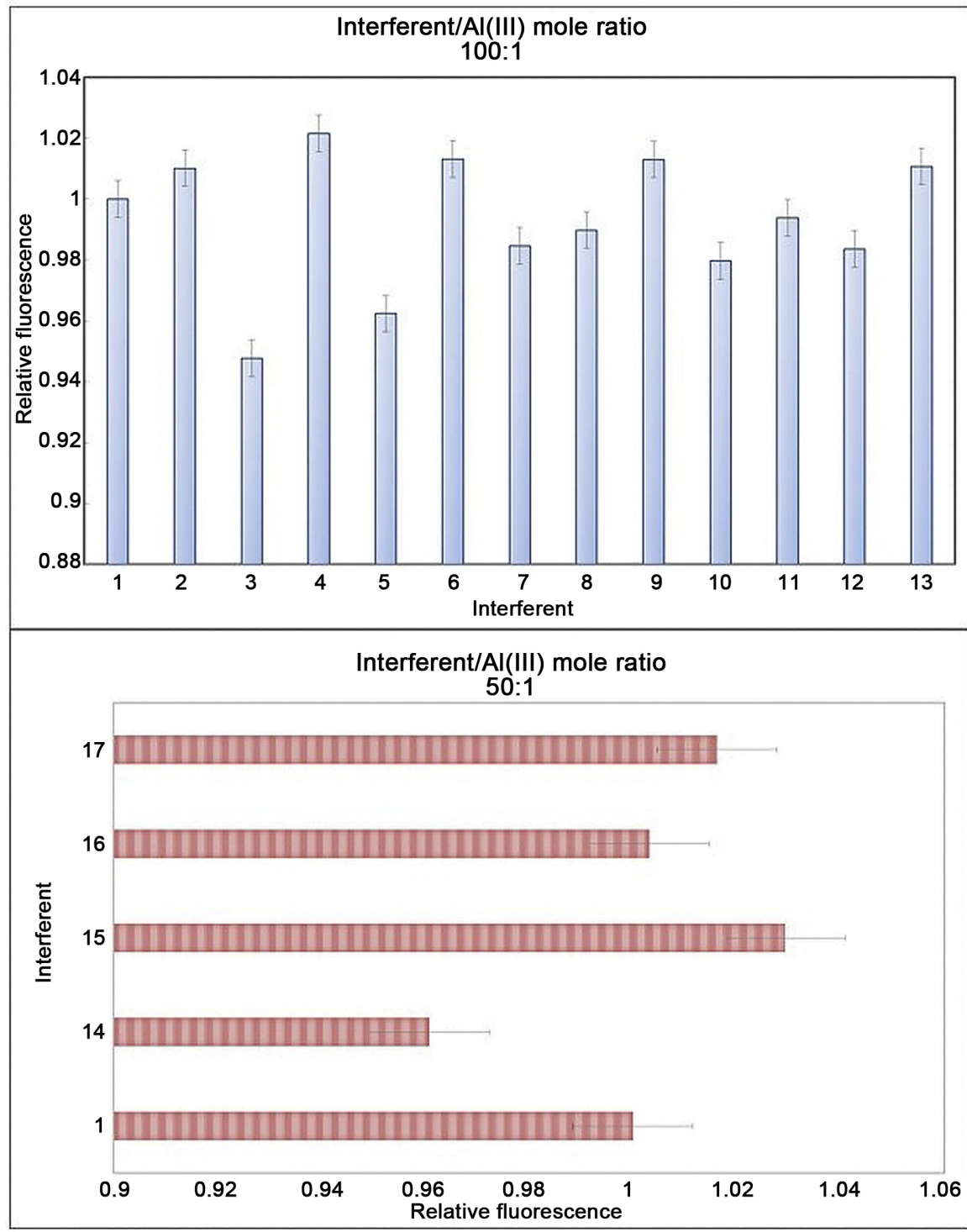

1: $\mathrm{Al}(\mathrm{III})=24.95 \mu \mathrm{g} \mathrm{L}^{-1} ; 2:$ Idem 1 in presence of $\mathrm{Na}(\mathrm{I}) ; 3:$ Idem 1 in presence of $\mathrm{K}$ (I); 4: Idem 1 in presence of $\mathrm{Mg}$ (II); 5: Idem 1 in presence of Cd (II); 6: Idem 1 in presence of $\mathrm{Pb}$ (II); 7: Idem 1 in presence of $\mathrm{Zn}$ (II); 8:Idem 1 in presence of $\mathrm{Cl}^{-}$; 9: Idem 1 in presence of $\mathrm{F}^{-}$; 10: Idem 1 in presence of $\mathrm{I}^{-} ; 11$ : Idem 1 in presence of $\mathrm{CO}_{3}^{2-} ; 12$ : Idem 1 in presence of $\mathrm{SO}_{4}^{2-} ; 13$ : Idem 1 in presence of $\mathrm{PO}_{4}^{3-} ; 14: \mathrm{Idem} 1$ in presence of $\mathrm{Ca}$ (II); 15: Idem 1 in presence of $\mathrm{Ni}$ (II); 16: Idem 1 in presence of Tl (I); 17: Idem 1 in presence of Sb (III). Conditions: $\lambda_{\text {em }}=570 \mathrm{~nm} ; \lambda_{\text {exc }}=490 \mathrm{~nm} ; \mathrm{C}_{\mathrm{QZ}}=1.75 \times 10^{-6} \mathrm{~mol}$ $\mathrm{L}^{-1} ; \mathrm{C}_{\text {buffer acetic/acetate }}=5 \times 10^{-2} \mathrm{~mol} \mathrm{~L}^{-1} ; \mathrm{pH}=5 ; \mathrm{C}_{\mathrm{SDS}}=5 \times 10^{-4} \mathrm{~mol} \mathrm{~L}^{-1} ; \mathrm{C}_{\mathrm{Al}(\mathrm{III})}=24.95 \mu \mathrm{g} \mathrm{L}^{-1}$. Other experimental conditions are described under procedure.

Figure 6. Study of interferences of Al(III) quantification. \%SDs ( I-I ) have been included for each interferent. 
Table 3. Recuperation studies by aluminium determination in 24 hours urine samples.

\begin{tabular}{|c|c|c|c|c|c|c|}
\hline \multirow[b]{2}{*}{ Samples } & \multirow[b]{2}{*}{$\begin{array}{c}\mathrm{Al}(\mathrm{III}) \\
\text { added } \\
\left(\mu \mathrm{g} \mathrm{L}^{-1}\right)\end{array}$} & \multicolumn{3}{|c|}{ Proposed methodology } & \multirow{2}{*}{$\begin{array}{c}\text { ETAAS } \\
\begin{array}{c}\mathrm{Al}(\mathrm{III}) \\
\text { found } \pm \mathrm{SD} \\
\left(\mu \mathrm{g} \mathrm{L}^{-1}\right)\end{array}\end{array}$} & \multirow[b]{2}{*}{$\mathrm{RE} \%^{\mathrm{b}}$} \\
\hline & & $\begin{array}{l}\text { Al(III) found } \\
\pm \mathrm{SD} \\
\left(\mu \mathrm{g} \mathrm{L}^{-1}\right)\end{array}$ & $\begin{array}{l}\text { Recovery } \\
(\%, n=3)\end{array}$ & $\begin{array}{l}\text { Real Al(III) } \\
\text { contents } \\
\left(\mu \mathrm{g} \mathrm{L}^{-1}\right)^{\mathrm{a}}\end{array}$ & & \\
\hline \multirow{3}{*}{1} & - & $9.88 \pm 1.47$ & - & \multirow{3}{*}{7.41} & \multirow{3}{*}{-} & \multirow{3}{*}{-} \\
\hline & 24.95 & $31.88 \pm 1.42$ & 70.14 & & & \\
\hline & 49.91 & $61.26 \pm 1.49$ & 114.87 & & & \\
\hline \multirow{3}{*}{2} & - & $30.00 \pm 1.54$ & - & \multirow{3}{*}{22.5} & \multirow{3}{*}{$33.4 \pm 0.02$} & \multirow{3}{*}{10.17} \\
\hline & 24.95 & $60.66 \pm 1.53$ & 119.03 & & & \\
\hline & 49.91 & $77.05 \pm 0.97$ & 90.47 & & & \\
\hline \multirow{3}{*}{3} & - & $62.90 \pm 1.74$ & - & \multirow{3}{*}{47.18} & \multirow{3}{*}{-} & \multirow{3}{*}{-} \\
\hline & 24.95 & $92.96 \pm 0.70$ & 108.12 & & & \\
\hline & 49.91 & $113.23 \pm 1.27$ & 100.66 & & & \\
\hline \multirow{3}{*}{4} & - & $87.42 \pm 1.98$ & - & \multirow{3}{*}{65.56} & \multirow{3}{*}{-} & \multirow{3}{*}{-} \\
\hline & 24.95 & $111.82 \pm 1.86$ & 99.37 & & & \\
\hline & 49.91 & $137.59 \pm 2.22$ & 99.99 & & & \\
\hline \multirow{3}{*}{5} & - & $93.21 \pm 1.81$ & - & \multirow{3}{*}{69.91} & \multirow{3}{*}{$98.8 \pm 0.08$} & \multirow{3}{*}{5.65} \\
\hline & 24.95 & $113.91 \pm 1.47$ & 95.44 & & & \\
\hline & 49.91 & $145.24 \pm 2.14$ & 102.27 & & & \\
\hline \multirow{3}{*}{6} & - & $130.69 \pm 2.20$ & - & \multirow{3}{*}{98.02} & \multirow{3}{*}{-} & \multirow{3}{*}{-} \\
\hline & 24.95 & $156.38 \pm 2.88$ & 100.56 & & & \\
\hline & 49.91 & $180.22 \pm 2.87$ & 99.7 & & & \\
\hline \multirow{3}{*}{7} & - & $160.73 \pm 1.11$ & - & \multirow{3}{*}{120.55} & \multirow{3}{*}{$163.7 \pm 0.02$} & \multirow{3}{*}{1.81} \\
\hline & 24.95 & $186.28 \pm 1.37$ & 100.37 & & & \\
\hline & 49.91 & $210.34 \pm 2.67$ & 99.81 & & & \\
\hline
\end{tabular}

${ }^{\mathrm{a}}$ Real Al (III) contents $\left(\mu \mathrm{g} \mathrm{L}^{-1}\right)$ : $\mathrm{Al}(\mathrm{III})$ founds $\left(\mu \mathrm{g} \mathrm{L}^{-1}\right) \times \mathrm{fc} \mathrm{fc}_{(\text {correction factor) }}=$ dilution factor/preconcentration factor. ${ }^{\text {bo }} \mathrm{RE}=100 \times(\mid$ measured value - actual value $\mid) /$ actual value. 1-3: non smokersubjets. 4 and 5: smokers of ten cigarette/day. 6: smoker of more than twenty cigarette/day. 7: water pipe smoker.

important exposition sources which contribute to $\mathrm{Al}(\mathrm{III})$ found; between others, it can be mentioned foods and cooking modes (use of aluminum cookware).

\section{Conclusion}

Developed methodology proposes the $\mathrm{Al}(\mathrm{III})$ traces determination based in the formation of the fluorescent complex with QZ. The new method showed good sensitivity and adequate selective with good tolerance to foreign ions, and was applied to the $\mathrm{Al}(\mathrm{III})$ traces present in urine samples coming from subjects with different tobacco smoke exposition. Results were validated by ETAAS with an adequate concordance. Solid phase extraction strategy demonstrated the efficacy to eliminate the highly fluorescent matrix of urine and to concentrate metal 
traces allowed its determination by SSF. It constitutes a green alternative of conventional preconcentration methods with additional advantages including low cost, safety, using non-polluting solvents. Considering the results obtained by our research group in reference to $\mathrm{Al}$ (III) traces determination, it can be concluded that the San Luis studied population is exposed to multiple sources of exposure to this toxical metal. So it would be important its control and monitoring in order to reduce the exposition sources, especially those related to tobacco consumption in all different forms.

\section{Acknowledgements}

Authors gratefully thank to Instituto de Química San Luis - Consejo Nacional de Investigaciones Científicas y Tecnológicas (INQUISAL-CONICET, Project 11220130100605CO) and Universidad Nacional de San Luis San Luis (Project PROICO 02-1016) for the financial support.

\section{Conflicts of Interest}

The authors declare no conflicts of interest regarding the publication of this paper.

\section{References}

[1] http://www.alimentosargentinos.gov.ar/contenido/marco/CAA/Capitulo_12.php

[2] Tomljenovic, L. (2011) Aluminum and Alzheimer's Disease: After a Century of Controversy, Is There a Plausible Link? Journal of Alzheimer's Disease, 23, 567-598. https://doi.org/10.3233/JAD-2010-101494

[3] http://alzheimer.ca/en/Home/About-dementia/Alzheimer-s-disease/Risk-factors/Al uminum

[4] Stahl, T., Taschan, H. and Brunn, H. (2011) Aluminium Content of Selected Foods and Food Products. Environmental Sciences Europe, 23, 1-11.

https://doi.org/10.1186/2190-4715-23-37

[5] Ordonnance sur les produits du tabac et les produitscontenant des succédanés de tabacdestinés à êtrefumés (Ordonnance sur le tabac, OTab) du 27 octobre 2004 (Etat le ler octobre 2012). https://www.admin.ch/opc/fr/classified-compilation/20021287/index.html\#a4

[6] Pappas, R.S. (2011) Toxic Elements in Tobacco and in Cigarette Smoke: Inflammation and Sensitization. Metallomics, 3, 1181-1198. https://doi.org/10.1039/c1mt00066g

[7] Abate, E., Hussien, S., Laing, M. and Mengistu, F. (2013) Aluminium Toxicity Tolerance in Cereals: Mechanisms, Genetic Control and Breeding Methods. African Journal of Agricultural Research, 8, 711-722.

[8] Bondy, S.C. (2010) The Neurotoxicity of Environmental Aluminum Is Still an Issue. NeuroToxicology, 31, 575-581. https://doi.org/10.1016/j.neuro.2010.05.009

[9] Malluche, R.H., Mawad, H. and Monier-Faugere, M. (2010) Renal Osteodystrophy in the First Decade of the New Millennium: Analysis of 630 Bone Biopsies in Black and White Patients. Journal of Bone and Mineral Research. https://onlinelibrary.wiley.com/doi/full/10.1002/jbmr.309

[10] Organización Mundial de la Salud (2013) Tabaco. Ginebra: OMS. 
[11] Encuesta Nacional de Factores de Riesgo, Sección TABACO, Ministerio de Salud de la Nación, Argentina (2015) http://www.msal.gob.ar/tabaco/

[12] Barbara Kamer, B., Pasowska, R., Matczak-Rynkowska, A., Socha-Banasiak, A., Kałużna-Czaplińska, J., Grys, W. and Rynkowski, J. (2013) An Evaluation of Cotinine as an Index of Exposure to Tobacco Smoke in Children with Recurrent Respiratory Tract Infections Using HPLC Method. American Journal of Analytical Chemistry, 4, 54-62. https://doi.org/10.4236/ajac.2013.47A008

[13] Crotty Alexander, L.E., Shin, S. and Hwang, J.H. (2015) Inflammatory Diseases of the Lung Induced by Conventional Cigarette Smoke: A Review. Chest, 148, 1307-1322. https://doi.org/10.1378/chest.15-0409

[14] Li, R.L., Chan, Y., Lu, L., Shen, J. and Zhang, L. (2014) Cigarette Smoking and Gastrointestinal Diseases: The Causal Relationship and Underlying Molecular Mechamism. International Journal of Molecular Medicine, 4, 372-380. https://doi.org/10.3892/ijmm.2014.1786

[15] Nagasawa, Y., Yamamoto, R., Rakugi, H. and Isaka, Y. (2012) Cigarette Smoking and Chronic Kidney Diseases, Hypertension Research, 35, 261-265. https://doi.org/10.1038/hr.2011.205

[16] Bahram, M., Madrakian, T., Bozorgzadeh, E. and Afkhami, A. (2007) Micelle-Mediated Extraction for Simultaneous Spectrophotometric Determination of Aluminum and Beryllium Using Mean Centering of Ratio Spectra. Talanta, 72, 408-414. https://doi.org/10.1016/j.talanta.2006.10.047

[17] Tabrizi, A.B. (2007) Cloud Point Extraction and Spectrofluorimetric Determination of Aluminium and Zinc in Foodstuffs and Water Samples. Food Chemistry, 100, 1698-1703. https://doi.org/10.1016/j.foodchem.2005.10.015

[18] Al-Kindy, S.M.Z., Suliman, F.O. and Salama, S.B. (2003) A Sequential Injection Method for the Determination of Aluminium in Drinking Water Using Fluorescence Enhancement of the Aluminium-Morin Complex in Micellar Media. Microchemical Journal, 174, 173-179. https://doi.org/10.1016/S0026-265X(03)00025-0

[19] Ulusoy, H.İ., Gürkan, R., Aksoy, Ü. and Akçay, M. (2011) Development of a Cloud Point Extraction and Preconcentration Method for Determination of Trace Aluminium in Mineral Waters by FAAS. Microchemical Journal, 99, 76-81. https://doi.org/10.1016/j.microc.2011.03.013

[20] Sang, H., Liang, P. and Du, D. (2008) Determination of Trace Aluminium in Biological and Water Samples by Cloud Point Extraction Preconcentration and Graphite Furnace Atomic Absorption Spectrometry Detection. Journal of Hazardous Materials, 154, 1127-1132. https://doi.org/10.1016/j.jhazmat.2007.11.018

[21] Sun, M. and Wu, Q. (2010) Determination of Ultra-Trace Aluminum in Human Albumin by Cloud Point Extraction and Graphite Furnace Atomic Absorption Spectrometry. Journal of Hazardous Materials, 176, 901-905.

https://doi.org/10.1016/j.jhazmat.2009.11.121

[22] Patrolecco, L., Ademollo, N., Grenni, P., Tolomei, A., BarraCaracciolo, A. and Capri, S. (2013) Simultaneous Determination of Human Pharmaceuticals in Water Samples by Solid Phase Extraction and HPLC with UV-Fluorescence Detection. Microchemical Journal, 107, 165-171. https://doi.org/10.1016/j.microc.2012.05.035

[23] Baig, J.A., Kazi, T.G., Shah, A.Q., Arain, M.B., Afridi, H.I., Kandhro, G.A. and Khan, S. (2009) Optimization of Cloud Point Extraction and Solid Phase Extraction Methods for Speciation of Arsenic in Natural Water Using Multivariate Technique, Analytica Chimica Acta, 651, 57-63. https://doi.org/10.1016/j.aca.2009.07.065 
[24] Ciftci, H. (2010) Solid Phase Extraction Method for the Determination of Cobalt in Water Samples on Duolite XAD-761 Resin Using 4-(2-Pyridylazo) Resorcinol by FAAS. Current Analytical Chemistry, 6, 154-160. https://doi.org/10.2174/157341110790945472

[25] Vásquez, V., Báez, M., Bravo, M. and Fuentes, E. (2013) Determination of Heavy Polycyclic Aromatic Hydrocarbons of Concern in Edible Oils via Excitation-Emission Fluorescence Spectroscopy on Nylon Membranes Coupled to Unfolded Partial Least-Squares/Residual Bilinearization. Analytical and Bioanalytical Chemistry, 405, 7497-7507. https://doi.org/10.1007/s00216-013-7201-x

[26] Lemos, V.A. and David, G.T. (2010) An On-Line Cloud Point Extraction System for Flame Atomic Absorption Spectrometric Determination of Trace Manganese in Food Samples. Microchemical Journal, 94, 42-47. https://doi.org/10.1016/j.microc.2009.08.008

[27] Tuzen, M., Saygi, K.O. and Soylak, M. (2008) Solid Phase Extraction of Heavy Metal Ions in Environmental Samples on Multiwalled Carbon Nanotubes. Journal of Hazardous Materials, 152, 632-639. https://doi.org/10.1016/j.jhazmat.2007.07.026

[28] Vega, M., Augusto, M., Talío, M.C. and Fernández, L.P. (2011) Surfactant Enhanced Chemofiltration of Zinc Traces Previous to Their Determination by Solid Surphase Fluorescence. American Journal of Analytical Chemistry, 2, 902-908. https://doi.org/10.4236/ajac.2011.28104

[29] Bortolato, S.A., Arancibia, J.A. and Escandar, G.M. (2008) A Novel Application of Nylon Membranes to the Luminescent Determination of Benzo[a]pyrene at Ultra-Trace Levels in Water Samples. Analytica Chimica Acta, 613, 218-227. https://doi.org/10.1016/j.aca.2008.03.004

[30] Talio, M.C., Alesso, M., Acosta, M., Acosta, M.G., Luconi, M.O. and Fernández, L.P. (2013) Caffeine Monitoring in Biological Fluids by Solid Surface Fluorescenceusing Membranes Modified with Nanotubes. Clinica Chimica Acta, 425, 42-47.

[31] Santarossa, D.G., Talio, M.C. and Fernández, L.P. (2016) Aluminium Traces Determination in Biological and Water Samples Using a Novel Extraction Scheme Combined with Molecular Fluorescence. Microchemical Journal, 129, 274-280. https://doi.org/10.1016/j.microc.2016.06.026

[32] Fain, V.Ya., Zaitsev, B.E. and Ryabov, M.A. (2003) Electronic Absorption Spectra and Ligand Structure in the Metal Complexes of Quinizarin. Russian Journal of Coordination Chemistry, 5, 369-374. https://doi.org/10.1023/A:1023688104602

[33] Cheng, K.L., Ueno, K. and Imamura, T. (1982) Handbook of Organic Analytical Reagents. CRC Press, Boca Raton, 139-141.

[34] Allen, N.S. and Richard, A.M. (1990) Spectroscopic, Photochemical and Photoconductive Properties of a Novel Fluorescent Polymeric Complex of Quinizarin and Aluminium. European Polymer Journal, 26, 1229-1235. https://doi.org/10.1016/0014-3057(90)90033-Z

[35] Pramauro, E. and Pelizzetti, E. (1996) Wilson \& Wilson's Comprehensive Analytical Chemistry, Volume XXXI, Surfactants in Analytical Chemistry: Applications of Organized Amphiphilic Media. Elsevier, Amsterdam, Chapter 4.

[36] Gupta, V.B. and Shrivastava, A. (2011) Methods for the Determination of Limit of Detection and Limit of Quantitation of the Analytical Methods. Chronicles of Young Scientist, 2, 21-25. https://doi.org/10.4103/2229-5186.79345 